\title{
3. How Young People are Healing the World: An Activist Reflects on the Tikkun Youth Project
}

\author{
DANIELLE MCLAUGHLIN
}

\author{
No great oaths need to be sworn \\ No special colours need be worn \\ Your hair can be curly or straight or shorn \\ You only have to be born \\ Just like everyone else on earth \\ Human rights are yours from birth \\ ROBERT PRIEST, EXCERPT FROM "YOU ONLY HAVE TO BE BORN" IN THE \\ WOLF IS BACK, WOLSAK AND WYNN, HAMILTON, 2017
}

\begin{abstract}
Young people everywhere face prejudice and discrimination. They are targeted for the same reasons older people are - because of their race, ethnicity, religion, gender, disability, or social status. They may live in societies where they face violence and deep personal strife. In addition to all of this, youth face the additional burden of discrimination on the grounds of their age. Most societies do not see young people as full citizens worthy of having a voice. Despite these barriers, the young people who participated in the Tikkun Youth Project, from five very disparate sites and demographics, demonstrated remarkable resilience, creativity, and willingness to engage with their communities. As an activist, I examined the civic engagement and rights-awareness of the young activist-researchers who appear in the international media, as well as those participating in the Tikkun Youth Project. I conclude, with some optimism, that young people are not waiting to become leaders: they are taking the reins and are making a positive difference - today.
\end{abstract}

67 | How Young People are Healing the World 
A young man named Aphiwe, who was from the community called Khayelitsha, an informal township in the South African city of Cape Town, told me a story. He was out for an evening with his friends. They were drinking beer (perhaps underage) in a hot and crowded venue when he decided to step outside for a breath of air, bringing his drink with him. As he was standing in front of the building, he was approached by several police officers. They told him it was illegal for him to be outside with his drink. He asked them why. They responded by beating him and breaking both his arms. "Did you complain to the authorities?" I asked him. He looked at me as if I had not understood what he had told me. If asking the simple question "Why?" of a police officer could result in a severe beating, did I not understand what complaining about police would do? Aphiwe was cared for by his friends who were also activists. They helped him get medical attention and kept him in the group while he recovered. This young man knew his town and understood the likelihood that a police complaint would result in further injury, or even worse consequences. Unlike some of us from more privileged communities, Aphiwe understood what it means to live with violence.

As I was writing this chapter, I received the dreadful and tragic news that Aphiwe had been murdered. While I do not know the details, I was given to understand that his death was the result of a robbery gone terribly wrong. Aphiwe had only just learned that he had been accepted into a special program for talented young artists, likely the first person in his family to attend a post-secondary institution. His loss is immeasurable for his community, his family, and for his fellow activists. In all of the Tikkun study sites, we will continue to think about Aphiwe and mourn the loss we all feel for the brilliance he brought into our lives.

I am an activist. I have spent much of my life enraged about injustice whenever and wherever I have seen it. Fortunately for me, I have been able to take action. I spent much of my life working for a non-government organization, the Canadian Civil Liberties Association and Education Trust, that gave me the opportunity to create programmes for teachers, studentteachers, and for students from kindergarten through university. These programs encourage people to participate in their democratic communities. I believe that by asking pertinent questions, thinking critically, engaging in dialogue, and facing conflict, we can all learn to make a positive difference in our societies. I joined the Tikkun Youth Project as an activist and educator 
who wanted to find out more about the young people who have already learned to make a difference. What do they know about their rights? How do they experience their communities? What do prejudice and discrimination mean to them, and how do they approach injustice in their communities? I wanted to learn how the researchers and participants in the five sites of study would interact with one another, and how they could learn from their own research as well as from the experiences of others.

I am a researcher in the sense that I learn from my observations and my readings, and while I am a teacher in that I engage with students, I am not an academic. I do not have a university appointment even though I have taught thousands of university students and teacher-candidates. My focus over the last three decades has been on citizenship education. I believe that as soon as a child is able to express an understanding of fairness (or of injustice), he or she is ready to take part as a citizen. I believe strongly in rights-based education and seek to identify strategies and information that can assist learners at all stages in seeing themselves as rights-holders. What follows below are my own observations and reflections on some of the stories reported and performed, and on research completed by the Tikkun Youth Project researchers and participants.

We learned many poignant stories from the young people who participated in the Tikkun Youth Project's Artnote. Below I share just a few as examples because there are so many such amazing stories.

A young woman in Windsor told us that she became pregnant while still in school. She was faced with some deep and difficult choices: Would she be able to continue with her education? Could she manage motherhood and schooling at the same time? What would her family think? What kinds of stigma would she and her child face? What resources, if any, would be available to her in her community? Did she have the right to make demands on "the system?" She described how each of the choices open to her could lead down very different paths. Her acknowledgment of this conflict could be seen as the turning point where she moved from being acted upon by external forces, to being an actor - an activist who began to engage in her community at many levels.

During the Artnote, we met a family that had fled for their lives from wartorn Syria. They shared their experiences about landing in Canada, knowing little or no English or French. These families had very little expectation of what, if any support their new community could provide. The children did not know if they would be able to go to school and whether they would be 
welcomed or rejected by other children. What would happen to the family if the adults were not able to find work? How would they live in this new land? While their English language skills are still limited, these young people have the courage to tell their stories to both newcomers and people whose families have lived in Canada for generations. As they shared their poignant stories of fear and uncertainties that have plagued their lives for many years, we learned about the effects of war and loss on youth and their families and we could observe their determination to engage in positive ways with their new friends and community.

So many times children and young activists are told by more senior members of their communities that they will be the leaders of the future. This chapter will demonstrate that young adult activists are at the forefront right now; they are not waiting to become more experienced or more educated - they are leading their communities now in ways that their seniors cannot even understand.

What do these young leaders have in common and what are their differences? We will explore examples and stories about their involvement with what they identify as needs in their own lives and the lives of others. How have they done this? How do they facilitate change? Let's see what their community participation and leadership look like on the ground.

\section{Identifying "Them" and "Us"}

One of the critical triggers that motivates youth to activism is the polarization of communities divided by strong social factors such as race, ethnicity, social class, and the lack of opportunity for employment and/or education. The manner in which a young person chooses to identify him/ herself is a significant contributor to the choices they make when faced with injustice. The civic engagement/pedagogy literature demonstrates that when young people learn to consider dissent and disagreement in a positive light, when they can listen to the views of people who think differently, they are better prepared to engage as citizens (Osborne, 2005; Sears, 2018).

In each of the five Tikkun study sites, and in the wider context of their personal experiences, the young researchers have identified and come up against societal barriers to change. They have found that they themselves or 
others they know have faced unfairness and discrimination on a variety of grounds (Ontario Human Rights Commission, n.d.).

Among the barriers faced by the young researchers in our studies are sexism, racism, bias against their religions, social class, the community with which they identify, and the neighbourhoods where they live. Most of the young people faced intersectional barriers because they are discriminated against on more than one ground. While the barriers are unique to each situation, the young people in our study share an optimism and an understanding that they are powerful. Their response to inequity has not been to sit back in fear; it has been to take charge. They believe Malala Yousafzai when she said, "When the world is silent, even one voice becomes powerful" (Yousafzai, 2013).

Firstly, it must be said that young people throughout the world face discrimination and prejudice (Giroux, 2003; Pinker, 2012; Young-Breuhl, 2013; Youthism, n.d.). _The very fact of their young age means that many adults believe a diminished number of years of experience makes young people less than competent to act in a responsible and capable fashion. Even when presented with evidence that young people have taken and continue to take leadership roles, participate in their communities, and even act as caregivers for people both older and younger, they rarely receive the credit that is their due. But, it is even worse for many young people. They are frequently vilified and blamed for wrongdoing even before any wrong doing has taken place. And recent events around the world have demonstrated that children and youth are seen as less than the rights-holder they are.

With the United States using children under the age of majority as pawns in a dangerous political game, separating them from their families and their adults, placing them in cages (Shear, Stolberg, \& Kaplan, 2018), it is easy to understand how readily youth go from being humans of worth to bargaining chips. Their voices, even the voices of crying babies, are unheard.

In 2018, the attention of the world was drawn to a terrible event in the U.S. when a shooter entered a Florida high school and murdered 17 people. School shootings are not unique to the U.S., but they are certainly more prevalent in that country than in any other. The young survivors, however, responded in a way that has not been seen following previous school shootings - they organized (Yee \& Blinder, 2018). They asked the obvious question: "What is causing so many school shootings?" And came up with an obvious answer - guns. Now, a lot of political power in the United States is in the hands of the National Rifle Association (NRA). This lobbying organization 
is very popular and positions itself as a protector of the constitutional right to bear arms - The Second Amendment of the United States Constitution reads, "A well regulated Militia, being necessary to the security of a free State, the right of the people to keep and bear Arms, shall not be infringed" ("The Constitution of the United States," n.d.). But the students who are speaking up and organizing are not trying to further divide the country between the gun lobby and those who question all gun ownership. They are carefully asking the hard questions of politicians: how much money do you take from the NRA? And what are you going to do to protect children from school shootings? These young people want answers to their questions and they are not willing to wait until they are old enough to vote. They see themselves as powerful and they are using their media savvy to exercise that power in many creative ways. They point out that it is easier for a young person to buy an assault rifle than to buy a beer in their state (Beckett, 2018). They want this changed. Their points are narrow and direct - they do not want to further divide the country, they want to unify everyone around the issue of child protection.

While we honour their courage and ability to articulate strong positions, we must also focus on the backlash that their protest attracted. Let us have a look at a few of the comments that were posted on social media in response to the students' activities:

"It's time for adults to start listening to young people." Said every young person ever... and then they grew up. Young people are lucky to vote at 18 given their brains aren't fully developed until 25 . They'll just have to make due [sic] with vigor, health, unextinguished zest for life, etc. (Clarke, 2018)

"Sure, even though last week congress was asking Tide to change the Pod designs because young people were eating them. Sure, let them determine government policy" (Daly, 2018).

In addition, several of the most articulate young spokespeople were accused of being actors planted by a left-wing anti-gun conspiracy (Uyehara, 2018). They were not given credit or respect for the thoughtful language they used nor the action they demanded. Instead, in many cases, they were assumed to be "tools" of an older generation. Even when young people are directly affected by the tragedies and unfair actions of the societies in which they 
live, there are those who refuse to see them as equal participants in society. The attitude that our youth are generally nuisances can be seen everywhere.

However, these nuisances can be quite effective. In fact, in March 2018, a Republican candidate for the Maine House of Representative who was running unopposed made some ugly comments about two of the Parkland student survivors (Hansler, 2018). The reaction was swift. The students used social media to encourage qualified candidates to run in opposition to him. And in the end, the candidate stepped down, and another Republican and a Democrat decided to run for the office (Hansler, 2018). This is what democracy in the hands of such young activists looks like.

There are many instances of generalized or systemic discrimination and prejudice against the young. Take, for example, the use of high-pitched sounds in locations where young people gather. These sounds, known as "Mosquito tones," have been found to be audible only to people under the age of about 25 (Education.com, 2013). Because of the common assumption that when a number of young people gather, they will be up to no good, stores and certain public institutions have hired security companies to install machines that make these noxious sounds (Akiyama, 2010). The aim is that the groups will disperse or gather elsewhere. Because some of the locations include transit stops and public buildings, some have said that this is a discriminatory act that unreasonably limits young people's access to institutions and services that should be equally available to all (Akiyama, 2010).

Another example of such prejudice can be found in youth curfews. Many communities require people under the age of majority (or under 16) to be inside their homes, usually from about 10 p.m. to 6 a.m. the following morning. The penalty for disobeying such laws is often in the form of fines laid on the young person and/or on his or her responsible adult (e.g., Ottawa Police Service, n.d.). Again, these curfews are based upon the assumption that if young people are out and about at night, they are about to commit an offense.

Vandalism is nearly always assumed to be perpetrated by the young, even when no actual perpetrators have been caught. Interestingly, when vandals and graffiti artists have been caught, it is often found that they committed their acts in the late afternoon (Schwartz \& Wang, 2005). In other words, curfews might look like a good idea, but they are discriminatory and they don't work. The curfews keep young people who have no intention to commit offences under a kind of house arrest, while failing to catch the actual 
vandals. As well, a number of municipalities have seen their curfews successfully challenged under human rights acts (Yosowich, 2015).

While curfews may seem like a trivial limit to freedom for adults, they are, in fact, a breach of Canadian constitutional rights, and rights under the Universal Declaration of Human Rights (UDHR), such as liberty, equality, freedom of association, and the right to peaceful assembly. We need to remember that all of our rights are for everyone. There are no age limits in the Canadian Charter of Rights and Freedoms or the UDHR. While specific laws and by-laws limit rights according to age, such as the right to vote and the requirement to attend school, limits must be shown to be reasonable. If we treat our young people as if they are not rights holders, how can we expect them to stand up for the rights of others who experience injustice?

A third example of systemic discrimination against young people is the reduced minimum wage that many countries permit employers to pay to those workers who have not reached the age of majority. Even where two people are working side-by-side, doing the same task, the younger of the two may be paid a lower wage. There are a number of justifications for this. In the opinion of some policy-makers, the unemployment statistics are kept lower when employers can hire cheaper workers. Others see the lower wage as a way for younger workers to get into the workforce and gain experience. While there may be benefits that accrue to a young person who is able to get work when that job could either go to an older and higher paid worker or be automated, the decision to pay young people at a lower rate cannot be said to be anything other than a form of systemic discrimination. Merely because of a personal characteristic, in this case age, a group of people do not have access to the same benefit, in this case a living wage, that other citizens have.

Perhaps the most insidious form of discrimination faced by young people is the inability to be included in discussions where decisions are made about their lives. At nearly every level of policy-making, young people are excluded from discussions about their health, welfare, education, and social status. Even where young people hold seats on governing boards, their presence is frequently a mere token; they may not be able to vote or participate in decision-making in a meaningful way (Urist, 2014).

Most if not all democratic countries have age limits for voting rights. It is understood that young children cannot make the kind of sophisticated decisions that informed citizens need to make. However, the age of majority varies from country to country, and has also frequently been changed within countries. There is nothing magical about turning 18, 19, or 21. People mature 
at different ages. Yet, a test for knowledge, maturity, or responsibility could create even greater disparity. When asked, many young people would like to see the voting age lowered. They argue that this will lead to an increase in voter turnout and political engagement ("Top ten reasons," n.d.). They also point out that young people are already involved with their communities and are knowledgeable about those communities' needs ("Top ten reasons," n.d.). Their voices need to be heard in meaningful ways because the laws have critical effects on their lives. As some have said, legislation without representation is unfair and discriminatory (NCC Staff, 2018). In my view, there would be little disadvantage to lowering the voting age. Since such a small number of voters bother to show up at the polls, this could give committed young people an opportunity to see the effects of organizing and having an opinion. And just like everyone else, if they don't care, they are unlikely to vote. Age limits are not written in stone. They can be changed again and again, depending upon political will.

I feel that young people should be heard from in democratic societies, particularly because students and others under the age of majority are, in fact, subject to more laws than those who have achieved the age of majority. Because of their age, in nearly every country, children and young people are required by law to attend school. While these are clearly laws that benefit the youth and society in general, other than people who have been convicted of criminal offences, no law-abiding sector of society is otherwise compelled to be in attendance in a public institution. In addition, most countries compel expression from young people. They are frequently required to wear school uniforms, sing national anthems, recite prayers or pledges of allegiance to their country, or otherwise demonstrate affiliations to institutions they may or may not support. To my mind, it is amazing that we still find young people who can think clearly and analytically after they have experienced so many restrictions on their liberty and freedoms.

And yet, if we look critically at the media, we find ourselves in every community, in the presence of young people who are deeply engaged citizens. These are the kind of people who participated in the Tikkun Youth Project and who have, of their own volition, become leaders in their communities. Despite the specific barriers to participation enumerated below, the other chapters in this book detail the positive activities led by young people at each of the Tikkun research sites.

Each of the chapters of this book celebrates the strength and leadership shown by the young researchers and participants of the Tikkun Youth 
Project. Each group discusses its unique challenges and what the participants learned about overcoming those challenges. The Artnote performance summarized the findings and responses to injustice that each group experienced. As a member of the audience, I had the privilege to watch the performers and other audience members as they responded to what they saw, heard, and learned. It is important to note that each group had its own way of expressing the experiences that brought them to activism, yet the shared experience of injustice united the groups and the individual performers.

\section{Divisions and Barriers to Participation Identified by Tikkun Youth Researchers}

Kosovo. The young people who came to Canada from Kosovo were remarkable in their honesty and articulate expression about the divided society in which they live. The Albanian/Kosovar/Serbian racism, antiIslamic, anti-Roma segregation, post-war division and violence are part of their daily lives. They spoke about the symbolic but very physical barrier that the bridge over the Ibar River in Mitrovica has created in their community. This bridge is the border crossing between Serbia and Kosovo (Morina, 2017). It effectively keeps ethnic Albanians from mixing with and gaining the benefits that their Serbian neighbours enjoy. While the group of young people from this city who came to Windsor for the Tikkun Youth Symposium represented the diversity of ethnic origins in Kosovo, they each reported in private conversation the understanding that they would have been unlikely to get to know one another without making a concerted effort to do so outside of their separated communities. They also mentioned in personal conversation that their families were not particularly happy with their associating with people from the other ethnicities.

Nonetheless, these young people used the bridge, the symbol of their division, as a place to gather people of different ethnicities together to meet and speak together. They are working to heal the world. Their slogan "More bridges, fewer walls" was a succinct expression of their hopes and the barriers they fight to tear down.

Toronto. The young researchers in Toronto were also a mixed and intersectional group of people; in this case, all young women. Because they 
are all young women, they face the same discrimination all women everywhere face. Because most women of colour belong to minority religions or identify along the LGBTQ spectrum, they also face intersectional discrimination (Ontario Human Rights Commission, n.d.). They came from both immigrant and so-called "old-stock" Canadian communities, although none identified as having Indigenous heritage. When asked to identify barriers to participation in their communities, the researchers listed discrimination they, their friends, and colleagues had faced in the following categories: Immigrants are treated with greater suspicion than "old-stock" (first or second wave immigrant) Canadians; postal code discrimination meaning that certain neighbourhoods were assumed to be "bad" and that people who lived in these neighbourhoods faced more difficulty in getting employment, being treated fairly in school, and finding housing; parental education (class) discrimination; youth unemployment, particularly for youth from minority groups; anti-Islamic attitudes and prejudice; and discrimination on the grounds of sexual orientation.

A spoken-word piece by Toronto participant Shaza Ali, at the time a firstyear university student, expressed her feelings about the barriers she perceives in her community:

I think people want anger from me. I get the feeling that there's an expectation of outrage, a fiery passion turned into a sound bite for you to gawk at. But I'm not angry. I'm just uncomfortable. Maybe it's because I have the privilege not to be angry. Because although there have always been those who say that I'm not wanted here, those are voices I can tune out. Because I've heard them all my life, but from a distance at which it's just background noise to me. Because I have the ability to roam the streets without fearing that my name will be in an article about the rising rate of hate crimes against people of my religious heritage. But that noise is slowly turning up lately, to a point where even I can feel a certain unease growing. An unspoken hostility under the surface. And maybe it's because I'm not a poster child for my community, that I can get away with a mild sense of discomfort rather than a bullet. I'm expected to express how afraid I am when a mosque is shot up or burnt down, but ultimately, I'm not the one whose fear makes a difference. I don't slowly back away when I wake up for breakfast and see my family. I forget to see them as a threat to national security. I don't call a tip line when I'm hanging out with my friends. I 
forget I'm supposed to believe that they're sleeper agents of global jihad. And I forget that some still look at me that way too because I thought I'd done everything I can to be assimilate. I've tried taking every step to be integrated. I've tried being everything they said I should be to be wanted here. But even though it's not my name listed in the headlines of the articles, there's an ever-growing pile of newspapers. And I can't shake the feeling that one of these days it'll include a name of someone I know. And I then suddenly can't tune out the fact that there will always be those who will still never want us here, but at that point I don't know what else is left for me to try. I suppose that's why I can't muster the energy to perform anger and passion. Because truthfully? I'm just tired.

Despite being frustrated by the attitudes of those around her, Shaza Ali is a volunteer working with other young people to make a difference. While she articulates her despair at the situation Muslim people are facing in her community, she finds ways to reach out and to speak out about the unfairness she lives with. Shaza is engaged in using the arts, such as the spoken-word piece above, as a way to reach out to and interact with people of her own faith, as well those in the university community where she studies.

Another Toronto researcher, Talisha Ramsaroop, expresses the problem of "postal-code prejudice" in a TEDx video (TEDx Talks, 2015). She tells us about the violence of low expectations. In 2018, Talisha was presented with the first Pam McConnell Leadership Award for her community activism (Beattie, 2018). In receiving this award, Talisha talked about her plans to run for political office in the future.

Windsor. The work done by the young researchers in Windsor demonstrated efforts to overcome social class discrimination, discrimination against immigrants and refugees, as well as discrimination against young parents. The young activists identified poverty as a problem that can be addressed by raising the minimum wage to a level whereby working families can sustain themselves. Coming from a city that has experienced very high unemployment after the closing of many automotive plants and related industries, the Windsor youth were particularly aware of the unfairness faced by the under and unemployed in their community. Even though many of them were students, they had a unique understanding of the way an entire family's life changes when breadwinners lose their jobs.

The Windsor youth joined with unions and other workers to call for a \$15/ 
hour minimum wage (Chen, 2017). They did not let their youth stand in the way of acting for their community and their families. While young, these advocates were able to participate in a groundswell of activism that came from many sectors in their community, and in 2018, they and their fellow protesters were successful in seeing the Ontario minimum wage increased. While it is impossible to know, when there are many contributions to a cause, which actors had the greatest effect, it is fair to say that the effect of this success on the young activists is likely to be one where they see themselves as strong and effectual. Will they continue to influence public policy in their communities? It is my view that when they feel strongly about an issue, these young people will remember how effective they have been; they will remember the techniques they used, and they will again become activists. It is now a skill they have learned to use.

At this point, I would also like to address two of the other concerns brought forward by the Windsor participants: teenage motherhood, and fear of immigrants and refugees.

A young woman in the Windsor cohort reported on her experience of becoming pregnant and having a child while still in school. She described the fear she had of the stigma and the barriers she expected to find, both from within her family and from her social sphere. She also talked about the struggle to overcome these issues and the surprising support she found among some of those whom she had expected to reject her. There are innumerable scholarly and popular articles about the stigma and prejudice faced by young mothers in Western society (Ellis-Sloan, 2014), but there is also evidence that with the support of their families, and social and academic communities, there is no reason to believe that their lives will be any less successful or happy than those of mothers in other age groups.

I am the grandmother of two children who were born while my daughter, their mother, was very young. Both my daughter and her daughters have gone on to develop as forceful and successful women who are advocates for their own communities and who see themselves as strong and powerful. Having seen bus drivers leave young parents standing in the rain, doors not held for teen mothers pushing strollers, and open public hostility offered to young mothers and their infants, I am amazed by the resilience and willingness of these people to move ahead to assist not only people like themselves, but also other less fortunate members of our community. And they are not unique.

The young mothers overcame the stigma and rejection they faced by 
making demands on those around them: they would not accept negative attitudes. Young mothers are fully capable of civic engagement and participation. While the difficulties many of the researchers in the Tikkun cohort faced had the capacity of making themselves and other people bitter and disengaged, our participants in every locale appear to have turned their negative experiences into causes for action.

Along with the Windsor activists who have grown up in the community, the Tikkun Youth Symposium Artnote heard from a group of newly-arrived young Syrian refugees. With great courage, these English language learners told stories about their losses, their fears, and their hard work at settling into a culture and education system that is very new and foreign to them. With their families in the audience, the Syrian refugee young men and women told of their harrowing escape from war - and of their culture shock when making new friends in school. These school-aged children were able to articulate their gratitude for the help they received in Canada, but also helped the Canadians to understand what it means to be a refugee. In their words, "sharing these stories will ease the burden and make us open our arms to life."

Is Windsor, Ontario a unique community? I like to think that it is representative of the kind of small city that takes its role in society very seriously. With its history of autoworker union activism, its Multi-Cultural Council ("Cultural Diversity Training," n.d.), and the important anti-racist work of the late MP Howard McCurdy (MacKay, 2018), Windsor community members know that there is an expectation of diversity and acceptance. Does this mean that everyone lives harmoniously together in Windsor? Certainly not, but there appears to me to be an expectation that racism and prejudice will not be ignored. Perhaps this is one reason that the Tikkun Youth Project was started and centered in Windsor, Ontario.

Thunder Bay. The young researchers and their mentors in Thunder Bay are faced with ingrained negative attitudes toward Indigenous youth (Talaga, 2017). This community has experienced great loss. Young students from remote communities come to Thunder Bay seeking a high school education and find themselves unwelcome and endangered. Toronto Star reporter Tanya Talaga (2017) tells the story of seven students who attended Dennis Franklin Cromarty High School in Thunder Bay, only to die under mysterious circumstances. The young people who survive experience a lack of opportunities in education and employment; like Black youth in larger cities, Indigenous young people in the north are frequently targeted by police for 
interrogation even where no wrong doing is suspected. The story of A.J. Miles is an example of what happens to such Indigenous youth:

On November 7, 2007, a member of the Thunder Bay Police Service singled out, questioned, detained and photographed DFC student Abraham J. (A.J.) Miles during a school field trip to the Thunder Bay police station. A.J. Miles, who is from Fort Severn First Nation, was made to remove his Warchief Native Apparel shirt before being permitted to reunite with his school tour, causing him to feel humiliated, embarrassed and discriminated against. Nishnawbe Aski Nation (NAN) took the view that this was an example of unwarranted racial profiling and part of a larger problem in the Thunder Bay Police Service with unjustly accusing First Nations youth of gang membership. No charges were ever filed against A.J. Miles. A.J. Miles filed a public complaint with the Thunder Bay Police Service who found in January 2008 that while one of the officers involved had committed misconduct that it was not serious. The Miles family retained pro bono lawyers from Aboriginal Legal Services Toronto (ALST) who appealed the January decision to the Office of the Ontario Civilian Commission on Police Service. The Commission agreed with the arguments put forward by ALST and have decided to hold a hearing into the misconduct of the Thunder Bay Police Service officer. A.J. Miles is pursuing two other complaints against the Thunder Bay Police Service. (Nishnawbe Aski Nation, 2008)

After this experience, A.J. returned to his home community and did not complete his schooling.

While the Canadian government has issued apologies and some restitution to families and individuals who survived Canada's infamous residential schools as well as the "60s scoop" when large numbers of First Nations children were removed from their families and placed with white families, the aftermath continues to play a very large part in the over-representation of Aboriginal people who are homeless, incarcerated, and among the missing and murdered.

And yet, the young people who participated in the Tikkun Youth Project give all of us cause for hope:

Red Rock Indian Band's Ashley Nurmela also received the Advocacy and Activism Award during the May 5 awards ceremony for the Stand 
Up anti-racism campaign she ran at Confederation College over offensive and racist posts on social media.

"I'm very humbled by it," says the second-year Confederation College Native Child and Family Services student. "I didn't realize that it had made such a big impact on so many people so far and wide, not just in our community of Thunder Bay but in the region."

Nurmela plans to continue running the Stand Up campaign after she graduates from the Native Child and Family Services program this year. (Garrick, 2016)

Facing racism and many other barriers to community participation, some young people demonstrate remarkable resilience. They refuse to let others define the roles they play in the communities in which they live. While the young researchers and mentors from Thunder Bay were fully aware of the stigma and prejudice they face on a daily basis as young Aboriginal people living in a majority settler community, they choose to focus on the things they can change in their own communities. They do not deny that there are many difficulties, but instead use those difficulties to bring attention to the special needs of young people like themselves. A fine example of this is the video "The River Flows" created and recorded by youth in Pikangekum First Nation as a response to the suicide crisis in their community (Jinan, 2018).

Cape Town. As people who are living in the aftermath of Apartheid, the young researchers from South Africa are a new generation of activists. They learn about the history of their country, about the Truth and Reconciliation Commission (Magistad, 2017; "Truth and Reconciliation," n.d.), and about the many communities and forces that make up their complex society.

While there have been many changes in the political systems in South Africa, the fact remains that the Indigenous peoples and people of colour experience great inequality in access to education, as well as poor quality of schools and teaching for people living in "townships" (informal communities). Among the other challenges faced by the communities where young people who participated in the Tikkun Youth Project live are fear of violence; massive unemployment; lack of material resources; substandard housing; lack of clean and reliable sources of water (Evans, 2018); little access to computers and Internet; and lack of reading material in learners' first languages. In other words, these young people face racial discrimination and poverty from their earliest years. Again, however, the youth from Cape Town demonstrated remarkable resilience and willingness to participate in 
campaigns to make positive changes in their township as well as in their country.

As detailed in the chapter by our South African colleagues Dr. Salma Ismail and Lyndal Pottier, Equal Education_, a non-profit, non-government organization works with young people who want to see an education system that is fair for everyone in South Africa (Equal Education, n.d.). By learning how to organize, to peacefully protest, to demand specific standards and implementation of legislation to address the unfairness they experience on a daily basis, these young people become literate in democratic practices and learned in civic engagement (Equal Education, n.d.). They see themselves as powerful change agents who are alerting their country, as well as the rest of the world, to the ways they are treated unfairly. But much more importantly, the Equalisers are learning how to use their voices in effective and democratic ways.

An example of this is the way in which the organization combines lawful political pressure with litigation (Equal Education, 2018). First, the organization lobbied the government to establish education norms so that all learners would have an equal opportunity to attend fully functional schools with qualified teachers - and walls, a roof, electricity, and plumbing (Equal Education, 2018). Once they succeeded in getting that legislation passed, they went on to use the courts to make the government implement the standards promised. Equal Education (2018) says, "We have seen what the law can achieve in securing real changes in the provisioning of basic services and the provisioning of education - that is why we are continuing to fight for better legal frameworks".

Equal Education can demonstrate the success of their organizing efforts and actions:

Since EE won its first victory and the Norms were initially published, we have seen an improvement in school infrastructure. Since 2013, more than 1000 schools that did not have water, now have water. More than 2000 schools that did not have electricity, now have electricity. However, this is not enough. We fought for more. (Equal Education, 2018, para. 7)

Shortly after this announcement, a five-year-old child tragically drowned in a pit latrine in his school (Eyewitness News, 2014). This heartbreaking event was used as a trigger by activists. When media talks about the large numbers 
of people who live in dreadful conditions, it is easy for the audience to turn away, but when the terrible story of one child is told, people stop and pay attention. Equal Education had a platform and they used it. The President of South Africa then demanded a plan from the Minister of Education to implement the norms and standards as promised (ENCA, 2018). The wheels of democracy grind slowly, but, with young people continuing to put pressure on their governments, there is hope for change.

\section{Conclusion}

As a group of researchers and practitioners, we have learned a great deal from the young researcher-activists who participated in the Tikkun Youth Project. I think I can summarize my findings and observations as follows:

- Nearly all young people experience discrimination on the grounds of age.

- Many youth are subject to intersectional discrimination because of their gender, disability, sexuality, race, religion, social status, immigration status, marital status, or other grounds in combination with one another, as well as with their age (Ontario Human Rights Commission, n.d.).

- Young people are not blind to the inequality they and others face.

- The Tikkun youth represent a positive vision for the future because they believe they can make a difference.

- Young people who live in communities that are divided because of war, politics, race, religion, unemployment, poverty, and violence can use these divisions to draw attention to their needs. They are often willing to reach across the divide to fight for the rights of people unlike themselves.

- Young activists are not afraid to stand up and speak out when they find unfairness.

- Even when they do not have full democratic rights because they are minors, young people are willing to take leadership roles in their communities.

- Young activists are willing to use the resources they find in their 
communities. They believe that their communities, no matter whether they live in poverty or wealth, contain human and social resources that can be utilized to make a positive difference.

- Young activists see themselves as rights-holders and expect their communities to treat them with respect - even when they have repeatedly and consistently experienced oppression.

- Young activists see no need to wait in order to take action.

- While the Tikkun youth are leading complex lives with, in some cases, serious responsibilities, they remain civically engaged at a deep level.

- While the Tikkun youth are special in many ways, they are not untypical of young people world-wide.

- The Tikkun Youth Symposium held in April 2017 provided a unique opportunity for the five groups of young activists to learn the issues, advocacy styles, techniques, and ideas that originated in each of the other groups.

- Each group returned to their home communities refreshed and more confident in the capacity of young people to lead positive change.

- In the year following the Tikkun Youth Symposium, a number of the youth groups and individual activists have gone on to work for social and political change.

I believe the most important lesson we have learned from this three-year study is that there is enormous hope for the future of civic engagement. The interaction of the young researchers at the five Tikkun Youth Project sites may be the beginning of a very personal and also very political way for young activists to learn from one another. The world is small. People now have many ways to communicate with one another - and young people are at the forefront of using information and communication technologies. Friendships and alliances can exist across borders and time zones. The ability to consult one another about ways to make a difference, to share, and to borrow creative techniques for bringing attention to important issues has never been easier. Media are now in the hands of us all. Let us hope that our Tikkun youth continue to use their skills and knowledge wisely.

Recent world-wide demonstrations have shown that older activists can continue to work for the goals they have identified as crucial because they are being assisted, and in some cases even led, by confident, intelligent, and thoughtful young people. As we learn the techniques of peaceful activism together, we can trust that the world is in good hands. 


\section{References}

Akiyama, M. (2010). Silent alarm: The mosquito youth deterrent and the politics of frequency. Canadian Journal of Communication, 35(3), 455-471. Retrieved from https://www.cjc-online.ca/index.php/journal/article/ view/2261/2969

Beattie, S. (2018, March 7). First Pam McConnell award to be presented on International Women's Day. The Star. Retrieved from https://www.thestar.com/news/gta/2018/03/07/first-pam-mcconnellaward-to-be-presented-on-international-womens-day.html

Beckett, L. (2018, February 16). Most Americans can buy an AR-15 rifle before they can buy beer. The Guardian. Retrieved from https://www.theguardian.com/us-news/2018/feb/16/americans-ageto-buy-ar15-assault-rifle-mass-shootings

Chen, D. (2017, July 10). Hearing on Ontario minimum-wage increase coming to Windsor. The Windsor Star. Retrieved from https://windsorstar.com/ news/local-news/hearing-on-ontario-minimum-wage-increase-to-beheld-in-windsor

Clarke, D. (2018, February 23). Re: It's time for adults to start listening to young people [Blog comment]. Retrieved from https://www.huffingtonpost.ca/danielle-s-mclaughlin/adults-listeningyoung-people_a_23368897/

Cultural Diversity Training. (n.d.). Retrieved from https://www.theglobeandmail.com/news/national/in-the-fightagainst-racism-mp-howard-mccurdy-never-backed-down/ article38263803/

Daly, A. (2018, February 24). Re: It's time for adults to start listening to young people [Blog comment]. Retrieved from https://www.huffingtonpost.ca/ danielle-s-mclaughlin/adults-listening-young-people a 23368897/

Education.com. (2013, May 23). Sonic science: The high-frequency hearing test. Scientific American. Retrieved from https://www.scientificamerican.com/article/bring-science-home-highfrequency-hearing/

Ellis-Sloan, K. (2014). Teenage mothers, stigma and their 'presentations of self.' Sociological Research Online, 19(1), 1-13. https://doi.org/10.5153/ sro.3269

ENCA. (2018, March 16). Ramaphosa gives Motshekga deadline on pit toilets. 
Retrieved from https://www.enca.com/south-africa/ramaphosa-givesmotshekga-deadline-on-pit-latrines

Equal Education. (n.d.). Our movement. Retrieved from https://equaleducation.org.za/our-movement/

Equal Education. (2018, March 15). Statement: Today is day two of Equal Education's court case to fix the national school infrastructure law. Retrieved from https://equaleducation.org.za/2018/03/15/statementtoday-is-day-two-of-equal-educations-court-case-to-fix-the-nationalschool-infrastructure-law/

Evans, M. (2018, March 13). Divided to the last drop: Cape Town is running out of water. Its four million residents are urged to cut their consumption or else the taps will stop running. But far from uniting citizens in a common struggle, the crisis has revealed the depth of class divisions in a city where so many don't have taps of their own. CBC News. Retrieved from https://newsinteractives.cbc.ca/longform/day-zero-capetown?cnis=b7caaf07-445a-4fbb-b67b-c1f0f3e76a57*C*2387*0*0*A

Eyewitness News. (2014, January 26). Pupil's death prompts government action. Eyewitness News. Retrieved from https://ewn.co.za/2014/01/26/ Pupils-death-prompts-government-action

Garrick, R. (2016, May 19). Youth honoured at annual awards. Anishinabek News. Retrieved from http://anishinabeknews.ca/2016/05/19/youthhonoured-at-annual-awards/

Giroux, H. A. (2003). Zero tolerance, domestic militarization, and the war against youth. Social Justice, 3(2), 59-65. Retrieved from https://www.jstor.org/stable/29768187

Hansler, J. (2018, March 17). Maine House GOP candidate who insulted Parkland students drops out. CNN. Retrieved from https://www.cnn.com/ 2018/03/17/politics/maine-house-gop-candidate-drops-out/index.html Jinan, N. [Nwe Jinan]. (2018, March 9). N'we Jinan artists - "The river flows" // Pikangikum First Nation [Video File]. Retrieved from https://www.youtube.com/watch?v=N5D-1TyJmSE

MacKay, S. F. (2018, March 9). In the fight against racism, MP Howard McCurdy never backed down. The Globe and Mail. Retrieved from https://www.theglobeandmail.com/news/national/in-the-fightagainst-racism-mp-howard-mccurdy-never-backed-down/ article38263803/

Magistad, M. (2017, April 6). South Africa's imperfect progress, 20 years after the Truth \& Reconciliation Commission. Pri. Retrieved from 
https://www.pri.org/stories/2017-04-06/south-africas-imperfectprogress-20-years-after-truth-reconciliation-commission

Morina, D. (2017, March 2). Mitrovica's flashpoint bridge symbolises Kosovo's divisions. Balkan Transitional Justice. Retrieved from http://www.balkaninsight.com/en/article/mitrovica-s-flashpointbridge-symbolises-kosovo-s-divisions-03-01-2017

NCC Staff. (2018, October 7). On this day: "No taxation without representation!" Constitution Daily. Retrieved from https://constitutioncenter.org/blog/250-years-ago-today-no-taxationwithout-representation

Nishnawbe Aski Nation. (2008). Abraham J. (A.J.) Miles. In Nishnawbe Aski Nation Annual Report 2007/2008. (pp. 37). Retrieved from http://www.nan.on.ca/upload/documents/finance-2008-annualreport.pdf

Ontario Human Rights Commission. (n.d.). An introduction to the intersectional approach. Retrieved from http://www.ohrc.on.ca/en/ intersectional-approach-discrimination-addressing-multiple-groundshuman-rights-claims/introduction-intersectional-approach

Osborne, K. (2005). Political education and citizenship: Teaching for civic engagement. Education Canada, 45(1), 13-16. Retrieved from https://eric.ed.gov/?id=EJ736046

Ottawa Police Service. (n.d.). Youth curfews. Retrieved from https://www.ottawapolice.ca/en/safety-and-crime-prevention/YouthCurfews.aspx

Pinker, S. (2012, March 2). Childism, by Elisabeth Young-Bruehl. The Globe and Mail. Retrieved from https://www.theglobeandmail.com/arts/booksand-media/childism-by-elisabeth-young-bruehl/article550457/

Schwartz, A., \& Wang, L. (2005, April 1). Proliferating curfew laws keep kids at home, but fail to curb juvenile crime. National Center for Youth Law. Retrieved from https://youthlaw.org/publication/proliferating-curfewlaws-keep-kids-at-home-but-fail-to-curb-juvenile-crime/

Sears, A. (2018, November 28). Dark clouds and silver linings: The perils and possibilities of digital media for citizenship. EdCan Network. Retrieved from https://www.edcan.ca/articles/dark-clouds-and-silver-linings/

Shear, M. D., Stolberg, S. G., \& Kaplan, T. (2018, June 19). G.O.P. moves to end Trump's family separation policy, but can't agree how. The New York Times. Retrieved from https://www.nytimes.com/2018/06/19/us/politics/ trump-immigration-children-separated- 
families.html?hp\&action=click\&pgtype=Homepage\&clickSource=storyheading\&module $=$ a-lede-package-region\&region=top-news\&WT.nav=top -news

Talaga, T. (2017). Seven fallen feathers: Racism, death and hard truths in a northern city. Toronto: House of Anansi Press.

[TEDx Talks]. (2015, April 22). The violence of low expectations | Talisha Ramsaroop | TEDxYorkU. [Video File]. Retrieved from https://www.youtube.com/watch?v=EMF7lnhPnv8

The Constitution of the United States. (n.d.) Retrieved from http://constitutionus.com/

Top ten reasons to lower the voting age. (n.d.). Retrieved from http://www.youthrights.org/issues/voting-age/top-ten-reasons-tolower-the-voting-age/

Truth and Reconciliation. (n.d.). Retrieved from http://www.justice.gov.za/trc/

Urist, J. (2014, April 23). Should students sit on school boards? The Atlantic.

Retrieved from https://www.theatlantic.com/education/archive/2014/ 04/do-school-boards-need-student-members/361127/

Uyehara, M. (2018, March 30). The sliming of David Hogg and Emma Gonzalez. GQ. Retrieved from https://www.gq.com/story/the-slimingof-david-hogg-and-emma-gonzalez

Yee, V., \& Blinder, A. (2018, March 14). National school walkout: Thousands protest against gun violence across the U.S. New York Times. Retrieved from $\quad$ https://www.nytimes.com/2018/03/14/us/schoolwalkout.html?emc=edit nn 20180315\&nl=morningbriefing\&nlid $=912058020180315 \&$ te $=1$

Yosowich, M. (2015, November 30). Can youth curfews be legally enforced? FindLaw Canada. Retrieved from https://legalblogs.findlaw.ca/legal-life/ can-youth-curfews-be-legally-enforced-638/s

Young-Breuhl, E. (2013). Childism: Confronting prejudice against children. New Haven: Yale University Press.

$\begin{array}{llll}\text { Youthism. } & \text { (n.d.). } & \text { Retrieved }\end{array}$ https://challengingyouthstereotypes.wordpress.com/youthism/ 


\section{Additional Reading: Educating for Civic Engagement}

About us. (n.d.). Youth for Human Rights. Retrieved from https://www.youthforhumanrights.org/about-us.html

Acar, Y. G., \& Ulug, O. M. (2016). Examining prejudice reduction through solidarity and togetherness experiences among Gezi Park activists in Turkey. Journal of Social and Political Psychology, 4(1), 166-179. doi:10.5964/ jspp.v4i1.547

Alex, C. (2016, June 1). 'Flying colours': Thunder Bay students organize high school's first powwow. CBC News. Retrieved from https://www.cbc.ca/ news/canada/thunder-bay/thunder-bay-high-schoolpowwow-1.3609637

Avery, P. G., Levy, S. A., \& Simmons, A. M. (2013). Deliberating controversial public issues as a part of civic education. The Social Studies, 104(3), 105-114. Retrieved from doi:10.1080/00377996.2012.691571

Banks, J. A. (2008). Diversity, group identity, and citizenship education in a global age. Education Researcher, 37(3), 129-139. doi:10.3102/ $\underline{0013189 X 08317501}$

Dickson, G. (2018, March 18). Children's crusade. Encyclopaedia Britannica. Retrieved from https://www.britannica.com/event/Childrens-Crusade

Goraya, J. (2015, March 9). The overrepresentation of minority youth in Canada's criminal justice system. The Public Policy and Governance Review. Retrieved from https://ppgreview.ca/2015/03/09/theoverrepresentation-of-minority-youth-in-canadas-criminal-justicesystem/

Hung, V. (2013, January 30). Youthists \& age discrimination. The Huffington Post. Retrieved from https://www.huffingtonpost.com/hung-vo/whatdoes-bring-a-youthis b 2200679.html

McCann, J. A. (1995). Nomination politics and ideological polarization: Assessing the attitudinal effects of campaign involvement. The Journal of Politics, 57(1), 101-120. Retrieved from doi:10.2307/2960273

Mira, M. L. (2013). Pushing the boundaries: What youth organizers at Boston's Hyde Square Task Force have to teach us about civic engagement. Democracy $\& \quad$ Education, 21(1), 1-13. Retrieved from https://democracyeducationjournal.org/home/vol21/iss1/2/

Osler, A., \& Starkey, H. (2004). Study on the advances in civic education in education systems: Good practices in industrialized countries. London: 
Centre for Citizenship and Human Rights Education/Institute of Education.

Soden, G. J. (2013). Preparing citizen-agents: A review of teaching for dissent: Citizenship education and political activism. Journal of International Social Studies, 3(2), 92-97. Retrieved from http://www.iajiss.org/index.php/ iajiss/article/view/99

Xing, K., Chico, E., Lambouths, D. L., Brittian, A. S., \& Schwartz, S. J. (2015). Identity development in adolescence: Implications for youth policy and practice. In E.P. Bowers et al. (Eds.), Promoting positive youth development, advancing responsible adolescent development (pp. 187-208). Switzerland: Springer International Publishing. doi: 10.1007/978-3-319-17166-1 10

Yousafzai, M., \& Lamb, C. (2013). I am Malala: The story of the girl who stood up for education and was shot by the Taliban. New York: Little, Brown and Company. 